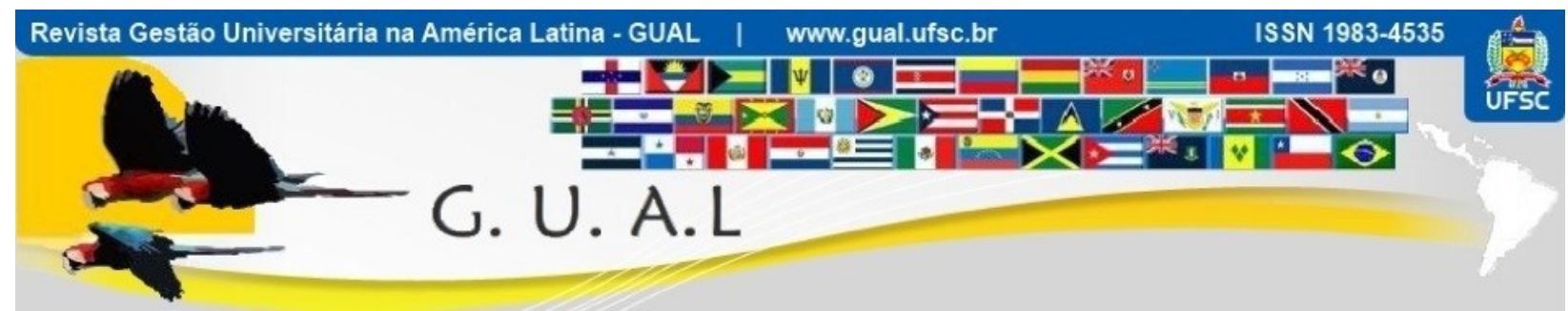

DOI: http://dx.doi.org/10.5007/1983-4535.2016v9n1p21

\title{
MODELING HIGHER EDUCATION ATTRACTIVENESS TO STAND GLOBAL ENVIRONMENT
}

\section{MODÉLISATION DE L'ATTRACTIVITÉ DE L'ENSEIGNEMENT SUPÉRIEUR POUR RÉPONDRE AUX DÉFIS DE L'ENVIRONNEMENT MONDIAL}

Leonel Cezar Rodrigues, Doutor Universidade Nove de Julho - UNINOVE leonelcz@gmail.com

Antonio Marcos Vivan, Doutorando Universidade Nove de Julho - UNINOVE vivan@uninove.br

José Eduardo Storopoli, Doutorando Universidade Nove de Julho - UNINOVE josees@,uninove.br

Recebido em 01/outubro/2014

Aprovado em 28/outubro/2015

Sistema de Avaliação: Double Blind Review

Esta obra está sob uma Licença Creative Commons Atribuição-Uso. 


\begin{abstract}
Inabilities to deal with the changing environment may lead Higher Education Institutions (HEI) to loose institutional attractiveness. Digital transformation requires global insertion as essential feature to institutional attractiveness. Processes for international education seem to lack the links between real environmental trends and the internal capabilities to global education. HEI managers may approach endeavors to internationalize education combining ambidextrous strategy supported by consolidated resilience capabilities. The latest ones refer to building internal value attributes to increase institutional attractiveness assuring solid standing in the global environment. In this article, a theoretical essay, we approach the problem of creating resilience as a way of backing up ambidexterity to generate institutional attractiveness. The set of value attributes, on the other hand, may originate strategic routes to strengthen internal competences and to make the institution more attractive, as a dynamic capability.
\end{abstract}

Key-words: Higher Education Management. Value Attributes. Global Environment. Ambidexterity. Resilience.

\title{
RÉSUMÉ
}

Incapacités pour faire face à l'évolution du contexte peuvent conduire Établissements d'Enseignement Supérieur (EES) à perdre attractivité institutionnel. Transformation digital demande insertion globale comme caractéristique essentielle à l'attractivité institutionnel. Processus pour l'éducation internationale semblent manquer les liens entre les tendances environnementales réelles et les capacités internes à l'éducation mondiale. Gestionnaires de les EES peuvent approcher efforts pour internationaliser l'éducation combinant stratégie ambidextre soutenu par les capacités de résilience consolidés. Les plus récentes se rapportent à la création de valeur interne attributs d'accroître l'attractivité institutionnelle assurant solide réputation dans l'environnement mondial. Dans cet article, un essai théorique, nous abordons le problème de la création de la résilience comme un moyen de sauvegarder l'ambidextrie pour générer attractivité institutionnel. L'ensemble des attributs de valeur, d'autre part, peut provenir routes stratégiques pour renforcer les compétences internes et pour rendre l'institution plus attrayant, comme une capacité dynamique.

Mots-clés: La Gestion de L'enseignement Supérieur. Attributs de Valeur. Environnement Mondial. Ambidextrie. Résilience. 


\section{INTRODUCTION}

Conceptual misleading and operational unpreparedness on global issues, nonetheless, may induce HEI's managers to drive internal endeavors that bolster global vision and values in the institution, to discontinuities and disruptions. One main reason could be that concepts, rol of academic units, and processes for global initiatives may lack the links between real environmental trends and the internal capabilities. Another reason could be that HEI managers neglect to adequately select and align the elements that forge institutional attractiveness, especially when it comes to stand the global revolving issues of today. In a recent research among students in Australia on intangible attributes that would support students' decision in the process of selecting universities, Shanka \& Terigin (2009) found that issues, such as, national and international recognition, and intercultural mix, were among the three valuable attributes on students' decision to apply for a university. Authors limit the research scope, however, to imply list intangibles attributes in the hopes that marketing department would find it useful to communicate with prospective students. Though the research did not go further on deepening the issue or evaluating strategies to address intangibles towards institutional attractiveness, it stands as useful evidences, from the point of view of students, of basic capabilities and competences of the institution that could become institutional attractiveness platforms.

To look at market aiming at finding what would be key in a university, as paradigm for attraction and retention of students, it is one way to approach institutional attractiveness. The rational here is to grind market perspective and behavior, finding opportunities and routes for institutional attractiveness. This vision conforms the concept of market pull technologies, where success depends on market standard of acceptance. Most expert literature on value attributes for Higher Education, however, (Tontini and Silveira, 2005; Mainardes, 2007; Broneman, 2003) identifies key elements of institutional attractiveness in a closer audience. That is, attractiveness is sought through students and alumni perceptions.

Another way to find key elements to attractiveness of a HEI is acknowledging the presence of institutional value attributes as internal resources. We think institutional value attributes as basic capacities. When well developed and consolidated inside an institution, they become a competence, in the concept of Prahalad and Hammel (1990). A well developed and unique set of attributes may become, therefore, the core competence of an institution, thus 
allowing not only to face global issues in the right way, but also to leverage on them to increase attractiveness.

The effectiveness of a strategy to conform an institution to stand global issues, however, it seems to begin with institutional ambidexterity (Birkinshaw and Gibson, 2004). In the one hand, ambidexterity sets institutional alertness for adaptability to external changes. In the other hand, it sets for alignment. Here, contextual ambidexterity should best fit institutional interests. This is the kind of ambidexterity spread out through every single layer of institution, not specific unit or department, such as, public relation or marketing. Adaptability is better achieved when from the president down to each professor and technical staff of the institution pay attention to what is going on in the external environment. Global issues become a necessary matter especially to faculty, so they would transfer knowledge in a global perspective. Both as a matter of perspective, as either a matter of enlarging institutional horizons, looking and thinking global pushes the institution to a distinctive level in the mind of prospective students. For increased attractiveness, being contextually ambidextrous becomes a strong mind inducer to prospectives, because of the interdisciplinary implication on careers and professions in modern society. As a result, they directly influence curricular contents and administrative drives in HEI.

In ambidexterity, the other face of adaptability is alignment. It refers to a combination of internal resources, technologies and processes to fit institution to better deal with existing and upcoming environmental issues. Alignment, of course, needs a rational platform of values on which the institution would build its strengths, meaning institutional resilience casting attractiveness. The resilience of a HEI, therefore, relates to the ability of an institution to hold unchanged the response of preference from its audience in the midst of the pressure from environmental competition. In other words, resilience resembles the elasticity to market preference of an institution as competition pushes the audience away.

To build resilience, however, the institution must combine a set of actions, such as, innovation ability, process alignment and corporate attributes. Innovation ability falls within institutional technology domain. Process alignment is the internal essential action to reach adaptability. And corporate attributes attaches to tangible and intangible institutional values, which are core to profile attractiveness. Combining a distinct set of tangible value attributes will assure the consolidation of the needed intangible ones, demanded to institutional attractiveness. 
In this article, a theoretical essay, we approach the problem of creating institutional resilience, to cast attractiveness, in the context of global issues. We discuss possible route combination that would give a necessary resilience to an institution facing global issues as a matter of day-to-day achievement. We rationalize on value attributes an institution could build to strengthen itself, increasing attractiveness to prospective students and to deliver better educational services. Strategic routes could be set along the distinct value attributes to ensure effective management in HEI.

Essentially, all jobs, functions, post and responsibilities in an organization structure, or any institution in a nation depend on the good education of its representatives. It is also intuitive and rational to admit that good education origins in the effectiveness of a HEI. Therefore, one cannot deny the importance of a HEI well inserted and up to date to advances in the scientific, politic and socio-economic fields in order to build a competitive nation. Thus, developing attractiveness in HEI is not only relevant to superior performance of the institution but also to advances in the management in the context of HEI.

\section{THEORETICAL PRECEDENTS}

The relationship between institutional value attributes and attractiveness can be demonstrated through the ambidexterity theory (Birkinshaw \& Gibson, 2004) and the theory of organizational resilience, as the fundamental layers. Building on these theories, we show how value attributes can build resilience to gain attractiveness, in the context of global changes. Ambidexterity role is to guarantee to the institution the ability to identify global issues with significant implications on her performance, requiring internal alignment to increase attractiveness.

\subsection{AMBIDEXTERITY}

Ambidexterity reflects a dual complementary movement - adaptation and alignment an institution ought to do to respond environmental changes (Birkinshaw and Gibson, 2004). Adaptation means the ability to identify and quickly jump into new opportunities. Alignment involves internal adjustment and a sense of coordination and rationalization of processes and capacities in order to create institutional values. Thus, ambidexterity means institutional responsiveness (adaptation) to pressure and changes from external forces while rearranging (aligning) internal capabilities to deliver institutional objectives. Ambidexterous capabilities may be a difficult balance to be reached in an organization. Generally corporate strategies 
focus one process only: the adaptation or the alignment, which one, in a specific momentum, the organization needs to overcome a contextual or structural hurdle (Hamel and Välikangas, 2003). An one approach option leads the organization to a peak in performance for some time. The business model for that option (alignment or adaptation) succumbs next step because of failure in balancing internal endeavors into both routes.

By concept, traditional expert literature admits organizations as structurally ambidextrous entities (Duncan, 1976). However, the recent digital transformation calls for rearranging the organizational structure: from a collection of departments with distinctive function (some focusing internal, while others focusing external functions) as traditionally the way, to a more intertwined and interdependent system of functions among people. Here we may call it a process system function, with strong implications on how a HEI can become agile and more effective in performing institutional objectives (Dean and Bowen, 1994). Process system functions implies that people overrides functions structurally attributed to each departments communicating with the environment (clients, suppliers, partners, allies and even rivals) in search for demands and opportunities the organization could supply or provide.

By nature and operating approach, the process system functions in an organization roofs a new concept of ambidexterity, the contextual ambidexterity (Birkinshaw and Gibson, 2004). In fact, effective ambidexterity spreads among human resources in all hierarchical layer of the organization. Employees divide attention between adaptation and alignment, independent of their working place in the organization. The starting point to adapt and/or to align does not originate in organization's functional departments, but it originate from demand stimuli or market opportunities that employees find.

The effectiveness to deliver teaching and research results to its audience depends on how efficient becomes HEI's ambidextrous ability. Ambidexterity requires people with a more generalist profile, but with a higher degree of initiative and dividing "their time between alignment-focused and adaptability focused activities" (Birkinshaw and Gibson, p. 50, 2004). On the other hand, ambidexterity requires from top management the compromise to support a compatible organizational climate to ambidextrous behavior. The risk seen in many companies resides in the imbalance focusing alignment or adaptability emphasized by a company. Depending on the momentum, a company may focus on adaptability, for instance, and when business challenges change, requiring more of alignment, executives do not perceive the need for internal changes and the company may fall into ruin. So, the most important are: (a) to guarantee a balanced focus between alignment and adaptability; (b) 
understand the concept of ambidexterity and contextual ambidexterity; and (c) recognize internal implications to stimulate contextual ambidexterity.

\subsection{RESILIENCE}

Resilience refers to the ability of an institution to respond to external changes with similar effectiveness as before the stimuli (Reinmoeller and Baardwijk, 2005). In other words, a resilient organization or institution, as our case, will acquaint the impact of an external change, will absorb it and will react to it to the same or superior levels of organizational effectiveness as it was before the event's impact.

Resilient institutions acquire ability of self-renewal. Self-renewal means to quickly reposition the institution advantageously before the market segment they want to serve, or alternatively, to renew their own processes, structure and internal dynamics adjusting to a new situation. It also means to be able to innovate in products/services, or in the entire portfolio, as the challenges require. The main dimensions where self-renewal ability delivers involve: (a) corporate or institutional attributes; (b) risk protection; and (c) process capacitation.

Process capacitation refers to the renewal of procedures to keep up operating effectiveness. As most type of innovation within institutions are incremental in nature, process capacitation becomes essential to allow institution to react appropriately, and quickly, before challenges it faces. In other words, process capacitation, while supporting drives to innovation, supports internal compensation of efficiency by process adjustments.

Risk protection refers to the ability of the institution to guarantee its own continuity by protecting the social and economic transactions of its business as a whole. Business here means the essential object of the socio-economic transaction of the institution. Therefore, institutional business represents any kind of transaction to deliver on education, knowledge transfer, research and services an HEI has been established for. Thus, risk protection reflects the compensation matrix an HEI follows to blind external challenges to the institutional effectiveness (process, product or service). As the institution does not lose effectiveness because of its arsenal of alternatives to face challenges, it becomes much protected to external demands from environmental disturbances. We call institutional elasticity, or simply, resilience, the limits of the institutional performance immutability to influences of external changes. Thus, resilient institutions tend to show higher elasticity to crises, keeping unaltered institutional attractiveness. 
Corporate or institutional attributes regards to a set of value attributes perceived by users, responsible for creating attachments between the users and the institution. While developing attachments, value attributes increase the right attractiveness of the institution towards users. For instance, designing curricula for global learning (ACE, 2014) falls in the category of tangible, fundament value attributes. Resilience, thus, involves building value attributes, processes, capacities, technologies and deliveries that help institutions generate attractiveness to users (Hamel and Välikangas, 2003).

An important call among expert literature comes from Birkinshaw and Gibson (2004). They pinpoint three processes to build institutional resilience: (a) exploration; (b) knowledge management; and (c) external cooperation or inter-institutional alliances. Exploration means search and use of external sources or recombination of new knowledge available within the institution to build capacities. With the same objective, knowledge management focuses on the reuse of internal knowledge, tacit or explicit, available in the institution. External cooperation or inter-institutional alliances concentrate on assessment and use of partners' knowledge, be it complementary or new knowledge.

In terms of analysis for decision-making, value attributes are the basic elements through which users perceive the benefits of educational services. Users buy them (education services), because the weight of value attributes results in benefits greater than the perceived cost to acquire them. The assumed implication, in terms of attractiveness, we can say, that as an institution becomes resilient, the greater is the elasticity of its attractiveness.

\subsection{VALUE ATTRIBUTES}

Generically, we understand value attributes as the benefit associated to a product or service an organization makes available to its clientele. In the Higher Education context, value attributes refer to the benefits - such as quality, performance, accessibilty - that add extra satisfaction to the service delivered, perceived by institutional services users. It normally comes associated to the educational services an institution provides to its audience as extra-bonus. We use Woodruff (1997, p. 142) concept of value as "the preference and evaluation of product attributes, performance of attributes and consequences from use them to facilitate reaching objectives and an end situation." Value attributes, thus, become reinforcing factors/elements to consolidate the institutional ability to keep interest from its audience. In this sense, value attributes are handle by institutions in unique ways to respond to external pressure with extra strength to keep audience sensitive to its objectives. 
Understanding the concept of value attributes is central to the argument of this essay. It's not hard to imagine from the concept, that value attributes come associated to the institutional attractiveness as essential part of it. As global issues influence in very distinct ways the effectiveness of the institution's attractiveness, value attributes will function as buffer between weaknesses and strengths guaranteeing attractiveness. In other words, constant changing of global challenges, in form and nature, require that value attributes would compensate the weakness of some service with the benefit of the value. The handling of attributes by the institution let her to show how much she cares for the students. By reinforcing perceptions of quality and delivery of educational services, value attributes, become the balance between basic acceptance and attractiveness of the institution's constituency.

From the expert literature, we can pinpoint a set of value attributes, that are, disperse among the understanding of management in HEI management. The list of attributes originates mostly from a list of attributes of two group approaches. One group of researchers, that includes Bronnemann (2003); Mainardes (2007); Mainardes and Domingues (2011), focuses on students perception of what values are important to student institutional attachment to an specific institution. All value attributes originate on students perspective about specific deliveries, such as accessibility; design; education quality; innovation; continuing education; professional success; institution image and differentiation, to name some. The authors do not classify the attributes based on their nature, but on user perception.

A second group, led by Tontini and Silveira (2005), focuses on value attributes under the institutional, rather than student perspective. Value attributes, such as replacement, continuing education; availability (of programs); compatibility and the likes, result from an internal assessment of institutional capabilities made available to students. Institutions pursue the development of their own capabilities to expand institutional value attributes, abiding by a strategic envision of what they want to be.

Classification of value attributes can also follow institutional own origins in nature. Under this perspective, values attributes are abstract or concrete, according to the degree of (in)tangibility (Lin, 2002). Price, for instance, holds a concrete nature value, while Trade Mark holds an abstract one. In this paper, we use a little distinct classification, grouping every value attribute as tangible or intangible.

Using a classification rationale based on tangible and intangible value attributes, a value matrix could be mapped down which could be helpful to create resilience and 
attractiveness into institutions. Figure 1 shows the basic set of value attributes an HEI must appropriate to gain trust in global environment issues.

\begin{tabular}{|c|c|c|c|}
\hline Intangible & \multicolumn{3}{|c|}{ Tangible Attributes } \\
\hline Personal & Operation & Fundament & Access \\
\hline Mark & Easy of use ${ }^{(3)}$ & Technology ${ }^{(9)}$ & Price \\
\hline Image & Usability ${ }^{(4)}$ & Quality & Financing \\
\hline Status & Professional Success ${ }^{(5)}$ & Compatibilidade $^{(10)}$ & Revolver Credit ${ }^{(14)}$ \\
\hline Differentiation & Updating ${ }^{(6)}$ & Integrated Education ${ }^{(11)}$ & Accessibility ${ }^{(15)}$ \\
\hline $\begin{array}{l}\text { Relative } \\
\text { Perception }^{(1)}\end{array}$ & Continuing Education ${ }^{(7)}$ & Design $^{(12)}$ & Availability ${ }^{(16)}$ \\
\hline Feeling $^{(2)}$ & Replacement $^{(8)}$ & Innovation ${ }^{(13)}$ & Impulse $^{(17)}$ \\
\hline
\end{tabular}

Figure 1 Value Attributes of HEI.

$1=$ Positioning $/ 2=$ Affiliation $/ 3=$ Professional Restrictions $/ 4=$ Usability of the Profession $/ 5=$ Alumni Success Index / 6 = Pedagogical Updating (content and professiographic Profile). $/ 7$ = Continuing Education (alumni) / $8=$ Replacement (curses, services) $/ 9=$ Educational Technology $/ 10=$ Professiographic Profile as expected by society / $11=$ Transdisciplinarity of contents; / $12=$ Appropriation of Institutional Values (value creation and seizure) $/ 13=$ Novelties; Differentiation $/ 14=$ financing in installments; / $15=$ Hurdles to entrance and level of retention / 16 = Product/services Major Portfolio; Ways and Local to access offer; / $17=$ Intuitive acquisition.

The matrix value attributes shows two categories of attributes, distinguished by nature: Tangible and Intangible attributes. Intangible attributes refer to attributes not touchable by individuals, however, perceived by the institution's audience (direct and indirect users), for instance, Trade Mark, Image, Status, Feeling and the likes. Because of their nature, intangible cannot be touched or directly manipulated. These attributes are unique to the institution and, in general, become the ultimate factors, responsible for institutional attractiveness.

Tangible represent those attributes the institution can manipulate directly. They can be observed, more than perceived, by users. Generically, tangible value attributes could be grouped into three categories: Functional, Fundament, Access. Access attributes, for instance, depend more on management practices. Fundament and Functional depend on faculty, as content builders (curriculum, material and knowledge builders) or as content deliverers.

\section{DISCUSSION}

Global trends mean threat, normally, but it could imply also good opportunity for HEI to increase attractiveness. Opportunities can be used if the institution is resilient to global 
pressures. Internal resilience is built through ambidexterity. An ambidextrous institution will struggle to find equilibrium between adaptability and alignment. Adaptability help the institution identify forces in the external environment with influence on operational effectiveness, optimization of resources and the right delivery of services and education.

Alignment may support better recombination of processes, educational technologies, capabilities and institutional competences. Alignment is necessary to guarantee the overall performance and back up to market strategy of the institution. The combination of adaptability and alignment would then drive the key elements that are a part of the institution's business model. Institutional ambidexterity, thus, becomes a critical instrument to start internal dynamics leading to a greater attractiveness.

The main implication of ambidexterity on HEI, reports to the institutional visibility. The permanent fit of HEI to its operating environment, indicates acceptance by society of institution's quality standards, when it shows compromise to deliver superior quality of educational services (Dalmarco et al., 2012).

One problem with ambidexterity, however, is that it has been structural in nature, up until now. Structural ambidexterity - where the institution holds some departments focused on internal and others focused on external activities - is not the answer to internal flexibility. For instance, academic departments are internalist in nature (Stankiewicz, 1986), but Marketing and International Relationships (IR) are externalist in character. International Relationships department does not always hold institutional power to make academic departments introduce global issues or to consider global issues in routine activities.

A new concept of ambidexterity, the Contextual ambidexterity pinpointed by Birkinshaw and Gibson (2004), must be now considered. Contextual ambidexterity transfers to individuals and groups, working along any hierarchical administrative or academic layer throughout the institution, the responsibility for identifying external opportunities and match them with internal solutions.

In this sense, it is important that HEI's top management rely upon specific policies and mechanisms to stimulate contextual ambidexterity. In fact, to deal with global issues and appropriate or optimize internal resources the institution needs to stimulate corporate entrepreneurship. The recognition and stimulus to various types of internal entrepreneurs, that is, academic entrepreneurs - multitask, cooperative, proactive and negotiators (Birkinshaw and Gibson, 2004), would bolster institutional competence, especially regarding to the necessary processes, capacities and competences that must be implemented to face global 
issues. If corporate entrepreneurs become centered model, the institution would be prompt from within to face global trend. Additionally, the institution would be much prepared to deal with the process of building internal resilience.

Figure 2 shows the implications of ambidexterity on institutional attractiveness, through institutional resilience. Contextual ambidexterity is the macro institutional mechanism that will prompt the institution to stand global trends. It allows the institution at the same time to identify global trends with implication over its offerings, select opportunities, point threads and define what would be the specific strategic issues (Bryson, 1995) the institution should deal with.

\begin{tabular}{|c|c|c|c|c|}
\hline \multirow{12}{*}{ 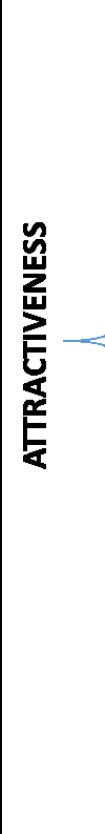 } & \multicolumn{4}{|c|}{ Contextual Ambidexterity } \\
\hline & INTANGIBLE ATTR & & TANGIBLE ATTRIBUTES & \\
\hline & INSTITUTIONAL & FUNCTIONAL & FUNDAMENT & ACCESS \\
\hline & Mark & Easy of use & Technology & Price \\
\hline & Image & Usability & Quality & Financing \\
\hline & Status & Professional Success & Compatibility & Installments \\
\hline & Differentiation & Updating & Integrated Education & Accessibility \\
\hline & Perception & Assistance & Design & Availability \\
\hline & Feeling & Replacement & Innovation & Impulse \\
\hline & & & & r \\
\hline & & Fact & Focus & Management Focus \\
\hline & & & Resilience & \\
\hline
\end{tabular}

Figure 2 Relationship between Ambidexterity, Resilience and Attractiveness.

Of course, this process cannot be monitored and determined top down with greater effectiveness than involving the institution as a whole, specifically the academic entrepreneurs. Institutional efforts to develop one or a specific set of values, therefore, should target at enhancing the intangible category of attributes that will guarantee attractiveness to prospective candidates. The addition of value attributes to the deliveries of an institution, however, can guarantee neither performance, nor attractiveness to the institution. Solutions generated to solve paradigmatic problems, originated in global, be it from political, economic, social and or educational scenario, require institutional skills to perceive and carry them on. 
The final target must always be to increase institutional attractiveness. As pointed above, contextual ambidexterity should be the first one of these instruments.

A second one, as important, it is resilience, based on a platform of value attributes. One way to look at resilience is to acknowledge Hamel and Välikangas (2003) vision, for whom resilience is a dynamic capability of an organization to self-renew through diverse and simultaneous sources of competitive advantage. Reinmoeller and Baardwijk (2005), on the other hand, argue that resilience is a basic case of corporate strategy. It relates, therefore, to an institution's ability to reinvent itself based on innovation. Exploration, knowledge management, cooperation and entrepreneurship are incumbent strategies to create corporate resilience. In HEI context, resilience based on value attributes may be used to overcome the global scenario's setbacks influencing institutional loss of attractiveness. The elements of the resilience - tangible and intangible attributes - serve as platform where resilience will straighten perceived deviation to students, such as outdating process and solutions.

Figure 2 shows the matrix of value attributes, classified into two dimensions Intangible and Tangible - and into four categories: Intangible Attributes: (1) Institutional Tangible Attributes: (2) Operational; (3) Fundament; and (4) Access. Institutional resilience regarding loss of attractiveness due to global trends not faced by the institution, counterparts losses with an array of well set value attributes. Institutional attractiveness is a function of well position institutional intangible attributes. However, visibility of intangible attributes, causing attractiveness, can only be increased or manipulated through the set of tangible ones. Access category, for instance, concerns mainly to administrative staff. In general, administrative decisions deal with price, financing policies and the likes in this category. Decisions not aligned with institutional or strategic objectives may cause damages to intangible attributes. For instance, if the institution operates in the social segment C and D Classes and under an international crisis with effects on the economy of the country, will ask for alternative solution other than price increasing if the number of students falls. Such bad decision could damage the image, the mark and the feeling attributes of the institution, because it could be seen as a sign of insensitivity of the institution towards the difficulties of the segment it serves. In consequence, there may be irreparable loss of attractiveness.

The next two categories (operational and fundament) link mainly to academic and teaching activities. It concern to curricula development, professiographic design of the degree, innovation (in format and content of curricula and courses), teaching excellence (quality) and the likes. Developing these attributes is not only a question of internal competence to change 
and evolution. It is also an acute sense of identifying demands and opportunities transparent among global trends, reached through contextual ambidexterity. It may be well evident the role of academic entrepreneurs, as defined here as the promptness to initiatives within institutional objectives. Faculty may explore academic opportunities for mobility (including student mobility), for research, for teaching and services. External alliances with internationally visible groups and experts to create visibility and internal capabilities are also a major part of developing operational and fundament value attributes.

The development of the tangible would assure consolidation of the intangible value attributes. Attractiveness, despite of being transparent to constituency of the institution may not be perceived through its tangible attributes, so it needs to build the intangible ones. Intangible attributes, in fact, influence perception of institutional constituencies bringing out feelings of attachment because of perceived benefits.

\section{FINAL REMARKS}

Our argument to generate institutional attractiveness is building it through resilience. However, resilience is not necessarily the answer to attractiveness. We see contextual ambidexterity in the institution as the trigger to spark the process of global issues capture and bringing them over to the attention of the institution community. Hence, it initiates internal alignment of resources, capacities and processes leading to resilience. Resilience, however, is not built only through value attributes as it classified above. It reports to alignment of the elements of corporate strategy (Rodrigues et al., 2004), development of tangible value attributes, consolidation of intangibles and, thus, enlargement of attractiveness. The responsive performance of the institution to external and global issues relies on people, mainly academic entrepreneurs. Specific resilient strategies must be added to alignment to ensure efficacy of value attributes and enhancement of attractiveness.

Contextual ambidexterity integrates tasks and function to create institutional resilience through value attributes, resulting in higher degree of attractiveness. We hope to have reach to the main results of this essay, that is, the demonstration of linkages between contextual ambidexterity as a major institutional strategy to straighten HEI before distinct forces in the global environment. Contextual ambidexterity becomes than the channel to align internal resources and to drive endeavors to build resilience, especially based on value attributes. The combination, emphasizing routes of tangible value attributes on the platform of resilience, will consolidate the intangible ones, with immediate reflects on institutional attractiveness. 


\section{REFERENCES}

ACE - American Council of Education (2014). Center for Internationalization and Global Engagement. Areas for Comprehensive Internationalization of Higher Education. Available at: http://www.acenet.edu/news-room/Pages/CIGE-About.aspx Acess: April 10 ${ }^{\text {th }}, 2014$.

Ben-David, J. (1971). The Scientist's Role in Society. Englewood Cliffs (NJ): Prentice Hall.

Birkinshaw, J., Gibson C. B. (2004). Building Ambidexterity into an organization. MIT Sloan Management Review, v. 45 (4), 47-54.

Bryson, J. M. (1995). Strategic Planning for Public and Nonprofit Organizations. San Francisco: Jossey-Bass.

Bronnemann, M. R. (2003). Marketing em Instituições de Ensino Superior: a promoção do processo seletivo. Anais do Coloquio Internacional sobre Gestión Universitaria en América del Sur [Proceedings of International Colloquium on Higher Education Management in South America], Buenos Aires, AR.

Dalmarco, G., Maehler, A. E., Dalmoro, M., Ladeira, W.J., Venturini, J.C. (2012). Inserção Internacional de Universidades e Valor Percebido - Uma análise em três Instituições de Ensino Superior [International Insertion of Universities and Perceived Value - A Three Higher Ed Institution Case Analysis]. Desenvolve - Revista de Gestão da UnilaSalle [Management Journal at UnilaSalle]. v.1(1), 8-35.

Dean, J.W. and Bowen, D.E. (1994). Management theory and total quality: improving research and practice through theory development.. The Academy of Management Journal, 19 (3), p. 392-418.

Duncan, R. A (1976). Organização ambidestra [Ambidextrous Organization]. In: Killman, RH, LR Pondy, e D. Sleven (eds.). Administração da Organização [Organizational Management]. New York: Holanda do Norte. 167-188.

Hamel, G., Välikangas, L. (2003). The Quest for Resilience. Harvard Business Review. No. $81,52-65$.

Mainardes, E. W. (2007). Atração e retenção de alunos em cursos de graduação em administração das instituições particulares de ensino superior de Joinvile, SC. (Master Thesis) [Attraction and Retention of undergraduate students of Management Programs in Private Institutions of Higher Education of Joinville, SC - Brazil. Universidade Regional de Blumenau, Brazil.

Mainardes E.W.; Domingues, M.J.C.S. (2011). Avaliação da Qualidade de Atributos Específicos de Instituições de Ensino Superior em Cursos Privados de Administração em Joinville, SC. [Evaluation of Specific Quality Attributes of Higher Education Institution at Joinville, SC- Brazil, for Management Programs] . Revista O\&S [O\&S Journal], 18(58), p. 429-444. 
Prahalad, C.K. and Hamel, G. (1990). The Core Competence of the Corporation, Harvard Business Review. 68(3), 79-91.

Reinmoeller, P., Baardwijk, N. (2005). The Link between Diversity and Resilience. MIT Sloan Management Review. v. 46(4), 60-65.

Rodrigues, L.C.; Maccari, E.A., Lenzi, F.C. (2004). Innovation Strategy for Business to Business Market Penetration. International Business Research Journal, 5(2), 137-149.

Shanka, T., Terigin, C. (2009). Intangible Attributes for Higher Education Choice. Marketing Insights; School of Marketing. Working Paper Series: no. 2009030, Curtin University of Technology.

Stankiewicz, R. (1986). Academics and Entrepreneurs - Developing University-Industry Relations. New York: St. Martin's Press.

Tontini, G. Silveira, A, (2005). Identification of Critical Attributes of Success in Products and Services: An alternative importance-performance analysis. Balas Annual Conference Proceedings. Madrid: Instituto de Empresa. p. 1-20.

Woodruff, R. B. (1997). Customer value: the next source of competitive advantage. Journal of Academy of Marketing Science, 25 (2), p. 139-54. 